\section{The Sun and Climate}

Many geologic records of climatic and environmental change based on various proxy variables exhibit distinct cyclicities that have been attributed to extraterrestrial forcing. The best known of these are the changes in Earth's orbital geometry called Milankovitch Cycles, with periodicities of tens to hundreds of thousands of years. However, many cycles seem to have subMilankovitch periodicities, commonly on decadal and centennial scales, similar to those of known solar cycles. A direct connection between solar irradiance (solar constant) and weather and climate has been suggested for more than 100 years but generally rejected by most scientists, who assume that the effect of solar variations would be small. However, recent satellite radiometer measurements and modeling studies indicate that small changes in total solar irradiance could produce global temperature changes of the magnitude suggested for climatic events such as the Little Ice Age (A.D. 1550-1700).

The best known and documented solar cycle is the 11-year sunspot cycle (Schwabe Cycle; fig. 1), during which the number of dark blotches (sunspots) on the sun's surface increases from a minimum to a maximum then back to a minimum over a period of about 11 years. The origin of sunspots is not fully understood, but thanks to satellites such as the Solar and Heliospheric Observatory (SOHO), scientists are learning rapidly. What is known is that during the period from A.D. 1645 to 1715 very few sunspots were observed. This period is called the Maunder Minimum (fig. 1) after E.W. Maunder, superintendent of the Solar Department of the Greenwich Observatory in England, who continued the observations of the German astronomer, Gustav Spörer (Eddy, 1976). Spörer noted a dearth of sunspots during a 70-year period beginning about A.D. 1645, and during an earlier 90-year period beginning about A.D. 1460 (now called the Spörer Minimum). An early association between sunspots and terrestrial phenomena was the observation that the number and intensity of aurora borealis sightings were greatest during sunspot maxima when the sun was most active (active sun), and lowest during sunspot minima (quiet sun). Another terrestrial observation was that the Maunder Minimum coincided with the coldest part of the Little Ice Age.

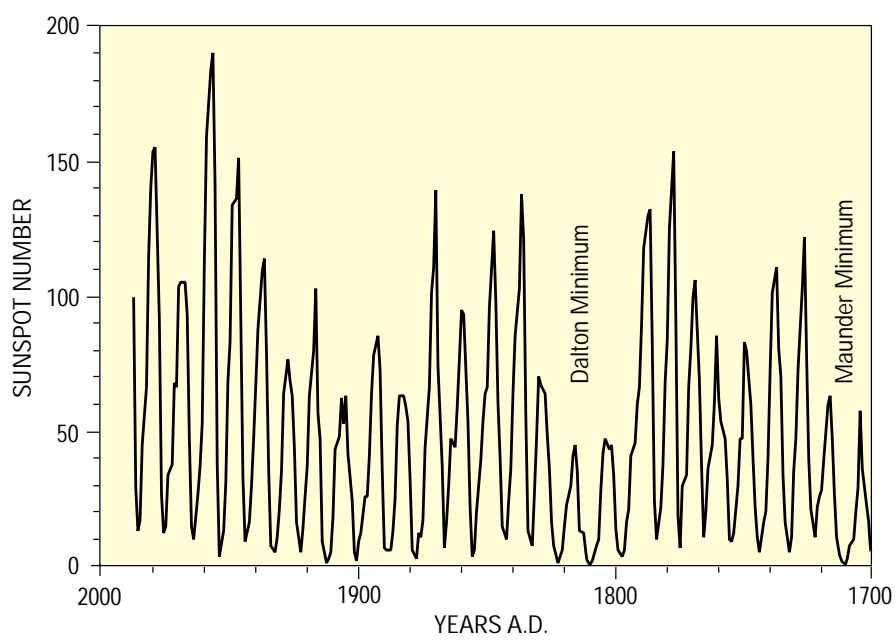

Figure 1. Record of sunspot numbers from A.D. 1700 to 1990 showing the 11-year Schwabe Cycle.

Recent studies have demonstrated that the production of radiocarbon $\left({ }^{14} \mathrm{C}\right)$ also is related to solar activity. Radiocarbon is produced in the upper atmosphere by bombardment of atmospheric nitrogen $\left({ }^{14} \mathrm{~N}\right)$ with neutrons from outer space (cosmic rays). An increase in solar activity (more sunspots) is accompanied by an increase in the "solar wind," which is an outflow of ionized particles, mostly protons and electrons, from the sun. The solar wind reflects cosmic rays and reduces ${ }^{14} \mathrm{C}$ production. Therefore, the ${ }^{14} \mathrm{C}$ concentration of the atmosphere is lower during sunspot maxima and higher during sunspot minima. The ${ }^{14} \mathrm{C}$ concentration of the atmosphere is recorded in the wood of trees. By measuring the ${ }^{14} \mathrm{C}$ content of wood from trees that are precisely dated by counting the annual tree rings, a relation between ${ }^{14} \mathrm{C}$ and age can be constructed, and commonly is expressed as $\Delta^{14} \mathrm{C}$ (for example, Stuiver and Pearson, 1986; fig. $2 A$ ), where $\Delta^{14} \mathrm{C}$ is the radiocarbon activity of the wood relative to mid-19th century wood. Such a reconstruction has been done for the last 11,000 years based on bi-decadal and decadal wood samples (for example, Damon and Sonnett, 1991). This reconstruction shows that ${ }^{14} \mathrm{C}$ production was much greater during the mid-Holocene (approximately 7,000 years ago), and steadily decreased until about 1,000 years ago. When this long-term secular variation trend in $\Delta^{14} \mathrm{C}$ is removed, the residual values show distinct cycles with periods of about 2,000 years (Hallstadtzeit Cycle; fig. 2B).

A closer look at the tree-ring $\Delta^{14} \mathrm{C}$ reconstruction for the last 1,000 years shows that ${ }^{14} \mathrm{C}$ was higher during the Maunder and Spörer Minima, but also shows that there were peaks in ${ }^{14} \mathrm{C}$ production centered on about A.D. 1300 and 1050 (fig. 3). These two periods of increased ${ }^{14} \mathrm{C}$ production are inferred to have also been periods of minimum solar activity, and are called the Wolf and Oort Minima, respectively. These cycles in ${ }^{14} \mathrm{C}$ production
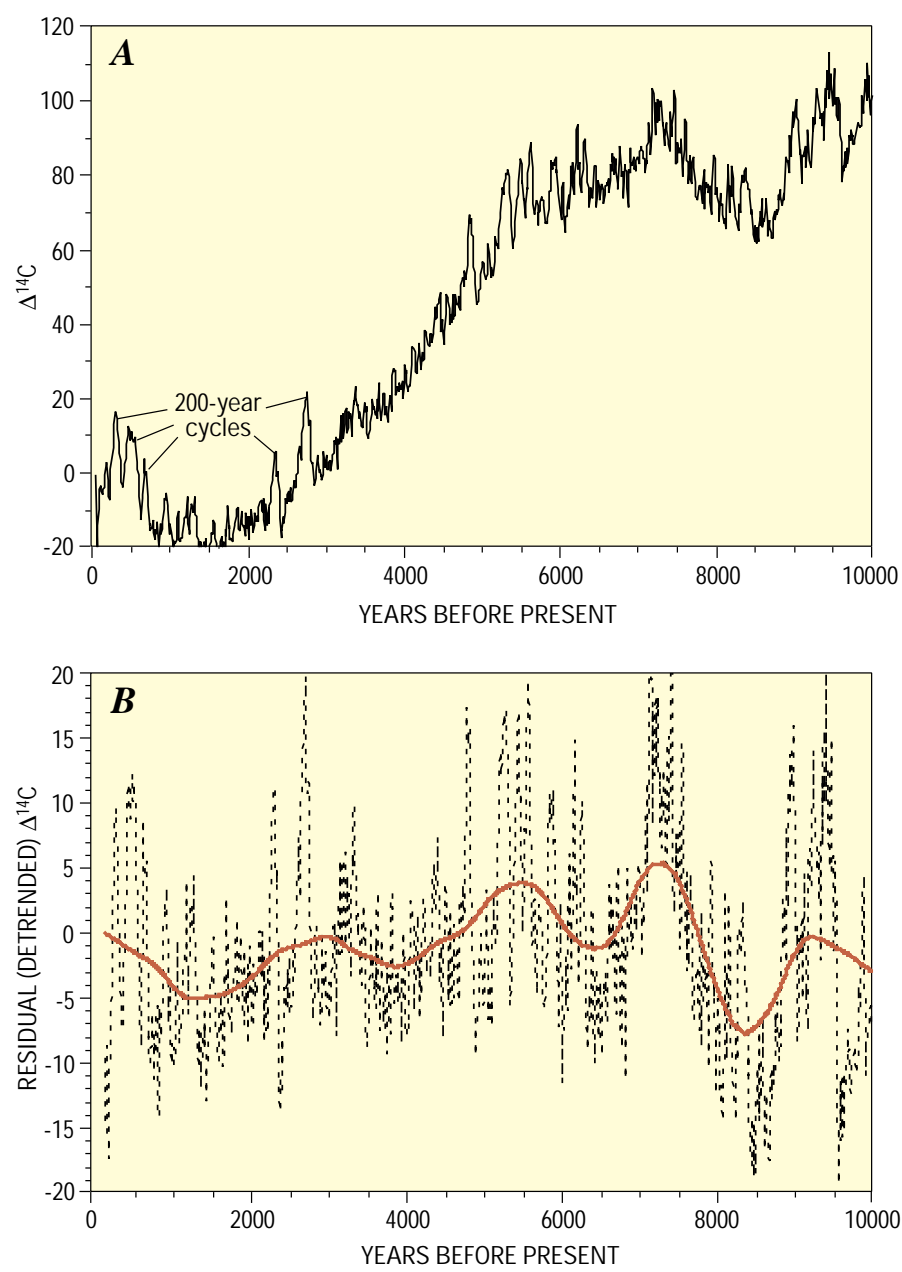

Figure 2. Records of radiocarbon production, $A$, as measured in bi-decadal samples of wood $\left(\Delta^{14} \mathrm{C}\right)$ in which the age of the sample is known from counting tree rings (Damon and Sonnett, 1991) for the period from 10,000 calendar years ago to the present. B, Residual (detrended; dashed lines) record of $\Delta^{14} \mathrm{C}$ in which the long-term secular variation trend has been removed. The heavy red curve is a weighted smoothing function showing Hallstadtzeit Cycles with periodicities of about 2,000 years. 

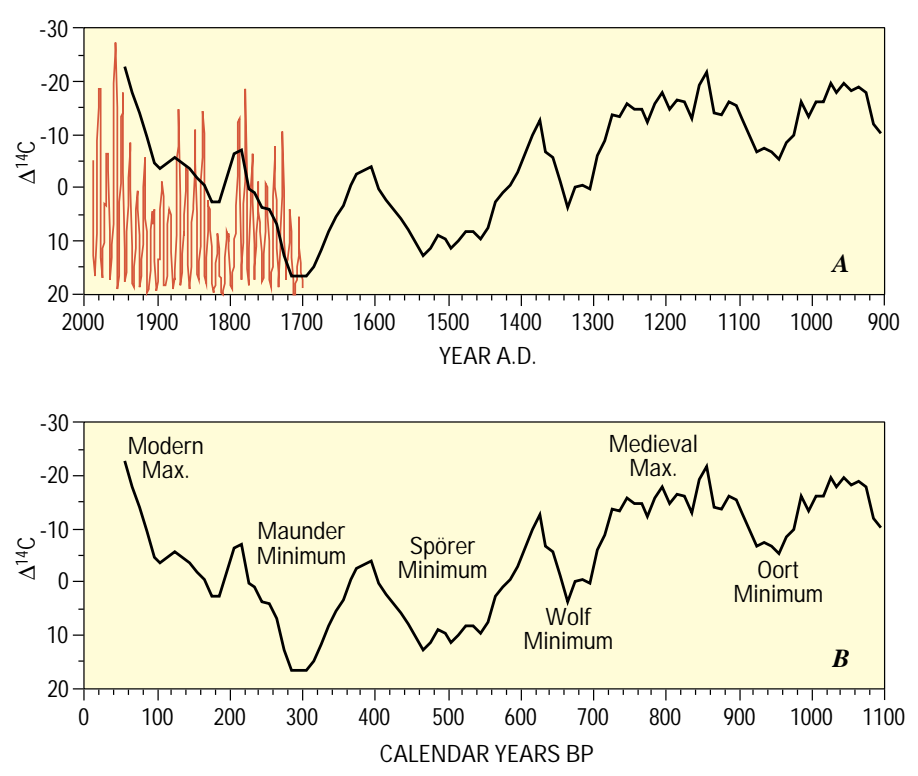

Figure 3. Details of the $\Delta^{14} C$ record for the last 1,100 years, in $A$, years A.D., and $B$, calendar years BP. The sunspot record from A.D. 1700 to 1900 (in red) is repeated from figure 1. Note that the scale of $\Delta^{14} \mathrm{C}(Y$-axis) is inverted relative to the same scale in figure 2 so that minima in $\Delta^{14} \mathrm{C}$ correspond to maxima in sunspot number. Note also that maxima in $\Delta^{14} \mathrm{C}$ lead minima in sunspot number; this represents the length of time (20-60 years) that it takes the radiocarbon signal in the Earth's atmosphere to respond to changes in solar activity. The cycles in sunspot minima ( $\Delta^{14} \mathrm{C}$ maxima) with periodicities of about 200 years are referred to as Suess Cycles.

and, by inference, in solar activity, have periodicities of about 200 years (socalled Suess Cycles; Damon and Sonnett, 1991), and cycles with similar periodicities can be seen in the longer $\Delta^{14} \mathrm{C}$ record (fig. 2). Note that the sunspot minima lead the $\Delta^{14} \mathrm{C}$ maxima by $20-60$ years, which is the time it takes for the effect of solar activity on ${ }^{14} \mathrm{C}$ production to cycle through the atmosphere-ocean system. When a spectral analysis is performed on the $\Delta^{14} \mathrm{C}$ record, a number of peaks appear in addition to spectral peaks at about 2,000 and 200 years (fig. 4). Two other prominent spectral peaks occur with periodicities of about 400 and 88 years. The 88-year cycle is called the Gleissberg Cycle and is thought to be the result of amplitude modulation of the 11-year Schwabe Cycle (Sonnett and Finney, 1990). A 22-year periodicity (not shown in fig. 4), the so-called "double sunspot" or Hale Cycle, also may be the result of amplitude modulation of the 11-year Schwabe Cycle. The prominent 200year cycles of Maunder-like minima (so called "Suess wiggles") may be the result of modulation of the $\approx 2,000$-year cycle (Sonnett and Finney, 1990). This makes it difficult to assign a cause to all but the basic 11-year sunspot cycle. The Maunder Minimum occurred during the coldest part of the Little Ice Age, but what can be said about global temperature during other sunspot minima and, for that matter, during sunspot maxima?

Satellite radiometer measurements made over the last 20 years have shown that total solar irradiance varies 0.1 percent over one 11 -year sunspot cycle, but that irradiance varies considerably with the wavelength of the electromagnetic radiation (Lean and others, 1995a). The variation of 0.1 percent in total solar irradiance over one sunspot cycle translates to a global tropospheric temperature difference of $0.5^{\circ}$ to $1.0^{\circ} \mathrm{C}$ (Labitzke and van Loon, 1993). Irradiance is greatest during sunspot maxima and lowest during sunspot minima-which appears to be counterintuitive because the dark sunspots might be expected to dim the sun. However, bright regions surrounding the sunspots, called faculae, cause the sun to brighten at peak activity (Lean and Foukal, 1988). Lean and others (1995a) estimated that during the Maunder Minimum, total solar irradiance was reduced by 0.2 percent relative to a present quiet sun (minimum of the mid-1990's), but total ultraviolet (UV) radiation was reduced by 1.04 percent. This is important because it is the UV radiation that modulates ozone production, which, in turn, affects the dynamics and energetics of the middle and upper atmosphere through radiative processes and dynamic mechanisms involving convective Hadley cell circulation (Haigh, 1996). Crowley and Kim (1996) estimated that a total warming of $0.8^{\circ}-0.9^{\circ} \mathrm{C}$ occurred between the minimum of sunspot activity during the Maunder Minimum and maximum sunspot activity during the mid-20th century. According to Lean and others (1995b), the surface of the Earth has warmed $0.55^{\circ} \mathrm{C}$ since 1860 , and about half of this could be due to increased solar warming since the Maunder Minimum. However, $0.36^{\circ} \mathrm{C}$ of the $0.55^{\circ}$ increase has occurred since 1970 . Solar forcing can only account for $0.11^{\circ}$ of the $0.36^{\circ}$ increase; the rest could be due to greenhouse warming or some other cause. Thus, there appears to be a real relation between solar activity and global temperature related to solar irradiance, with colder temperatures during sunspot minima. The period of low ${ }^{14} \mathrm{C}$ production between about A.D. 1100 and 1250 is called the Medieval Maximum of sunspot activity (fig. 3 ), and coincides in time with a warm interval referred to as the Medieval Warm Period. This is when the Vikings colonized southern Greenland and eastern Canada (Vinland; http://www.anthro.mankato.msus.edu/prehistory/ vikings/vikhome.html). The reasons for abandonment of the Greenland colonies are still being debated, but a likely contributing factor may have been the cold climate associated with the Wolf Minimum (fig. 3). Solar activity was generally low ( ${ }^{14} \mathrm{C}$ production high) during the period A.D. 1300 to 1900 , with two distinct lows, the Spörer and Maunder Minima (fig. 3). It has only been in the 20th century that solar activity has increased $\left({ }^{14} \mathrm{C}\right.$ production decreased) to levels that occurred during the Medieval Maximum (fig. 3).

Far more variable than changes in total solar irradiance are changes in amount of energy emitted as ultraviolet, extreme ultraviolet, and X-rays, and in the continuous outflow of ionized solar particles (solar wind), which controls the properties of the Earth's magnetosphere. The connection between solar activity, as measured by what solar physicists refer to as "coronal mass ejections" or CME's, and geomagnetic storms has been well documented in recent years. (See reviews by Cliver, 1994a, 1994b, and 1995.) A connection between geomagnetic storms and climate might form another link (in addition to solar irradiance) between the sun and climate, with geomagnetic storms as the intermediate step, driving zonal winds in the troposphere, the lower $10 \mathrm{~km}$ of the Earth's atmosphere where weather occurs. Roberts and Olson (1973) observed that strong solar-geomagnetic disturbances in the troposphere during winter were often followed within a few days by a deepening of subpolar low-pressure systems over the North

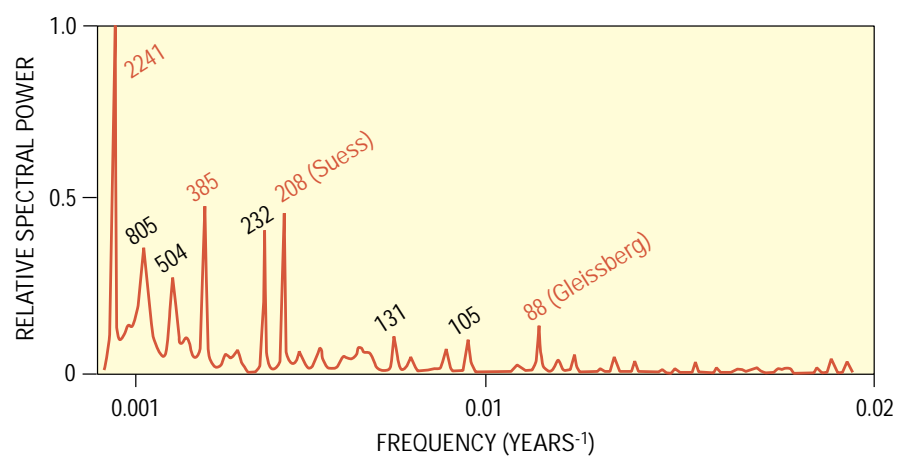

1000

100

PERIOD (YEARS)

Figure 4. Maximum entropy method (MEM) power spectrum of the tree-ring calibrated $\Delta^{14} \mathrm{C}$ record. Periodicities in red are discussed in text. Adapted from "Solar and Terrestrial Components of the Atmospheric ${ }^{14} \mathrm{C}$ variation Spectrum" by Paul E. Damon and Charles P. Sonnett in The Sun in Time, edited by C.P. Sonnett, M.S. Giampapa, and M.S. Matthews. Copyright $\odot 1991$ The Arizona Board of Regents. Reprinted by permission of the University of Arizona Press. 


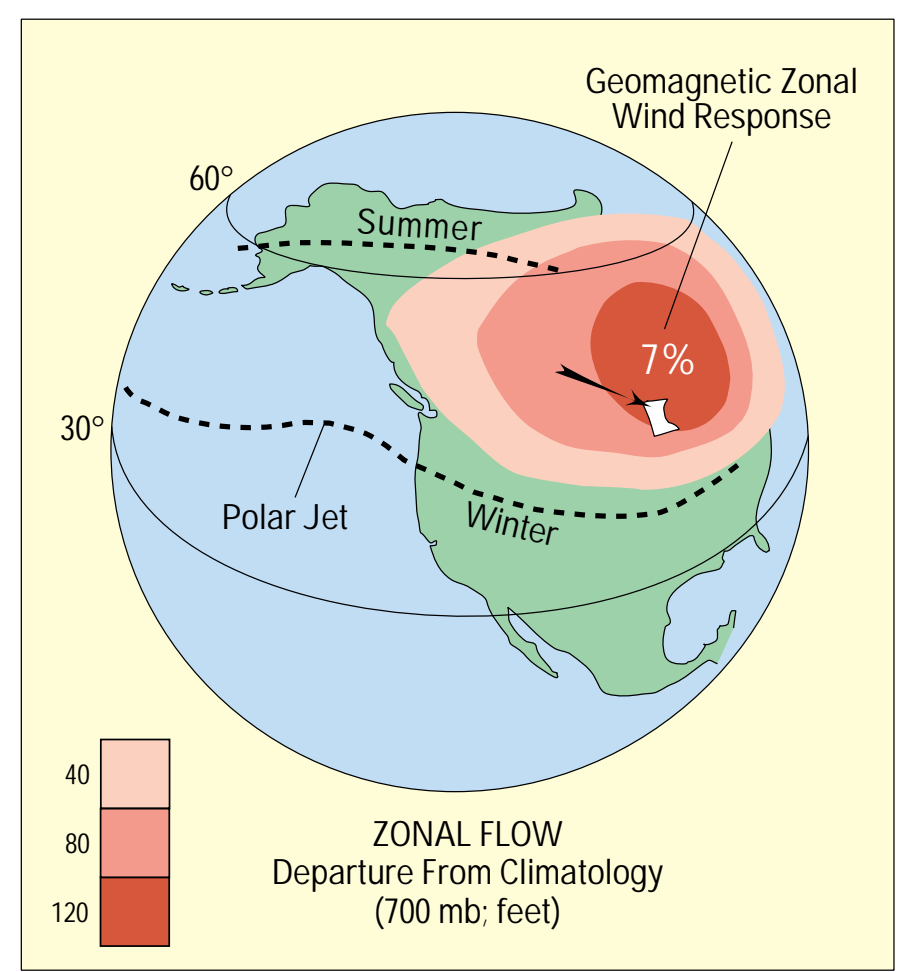

Figure 5. Location of North America with respect to the region of greatest increase in zonal winds following occasional solar-geomagnetic disturbances at the 700 millibar ( $\mathrm{mb}$; approximately $4 \mathrm{~km}$ elevation) level during the winter (Stolov and Shapiro, 1974), and the position of the core of the polar jet in winter and summer at 6,000 cal. yr. BP as computed by Kutzbach (1987). Shading represents lowering (in feet) of the $700 \mathrm{mb}$ level relative to the average height in winter for the period from 1947 to 1970 ("climatology"). The darkest areas with the largest departure in central North America correspond to a 7 percent increase in mean geostrophic westerly flow. Arrow shows the surface-wind trajectory during the mid-Holocene in north-central M innesota as determined from sand dune alignment (Grigal and others, 1976).

Pacific. Stolov and Shapiro (1974) studied the 700-millibar heights (about 4 $\mathrm{km}$ ) in the northern hemisphere between lat $20^{\circ}$ and $70^{\circ} \mathrm{N}$. in relation to solar geomagnetic disturbances over the period from 1947 to 1970 . They noted that the most significant response to these disturbances was a decrease in the 700-millibar height in winter relative to the average for the same period ("climatology") 4 days following a disturbance. The decrease is greatest over the North American Great Lakes area between long $70^{\circ}$ and $110^{\circ} \mathrm{W}$. and lat $40^{\circ}$ and $70^{\circ} \mathrm{N}$. It corresponds to an increase by as much as 7 percent in tropospheric westerly flow, which translates to an increase in mean zonal wind velocity of about $0.6 \mathrm{~m} \mathrm{~s}^{-1}$ (fig. 5). Statistical analyses by Tinsley and Deen (1991) of 33 years of meteorological data show a clear correlation between the intensity of cyclonic circulation in mid-latitude oceanic regions with changes in cosmic-ray flux following geomagnetic storms. The main effect of geomagnetic disturbances would be to increase westerly zonal winds from the North Pacific. These changes in zonal winds occur on a day-to-day time scale as well as on a decadal time scale related to the sunspot cycle.

These are several measured connections between solar geomagnetic storms and "weather" at the Earth's surface. Because geomagnetic storms are related to solar activity and cosmic-ray flux, and because ${ }^{14} \mathrm{C}$ is produced by cosmic rays, records of past ${ }^{14} \mathrm{C}$ production, as recorded for example in tree rings, might also serve as a paleowind indicator. The tree-ring record of ${ }^{14} \mathrm{C}$ production over the last 10,000 years shows that long-term production of ${ }^{14} \mathrm{C}$ was low during the last 4,000 years relative to that during the mid-Holocene $(8,000$ to 4,000 years BP; fig. $2 A)$. The Earth's geomagnetic field strength
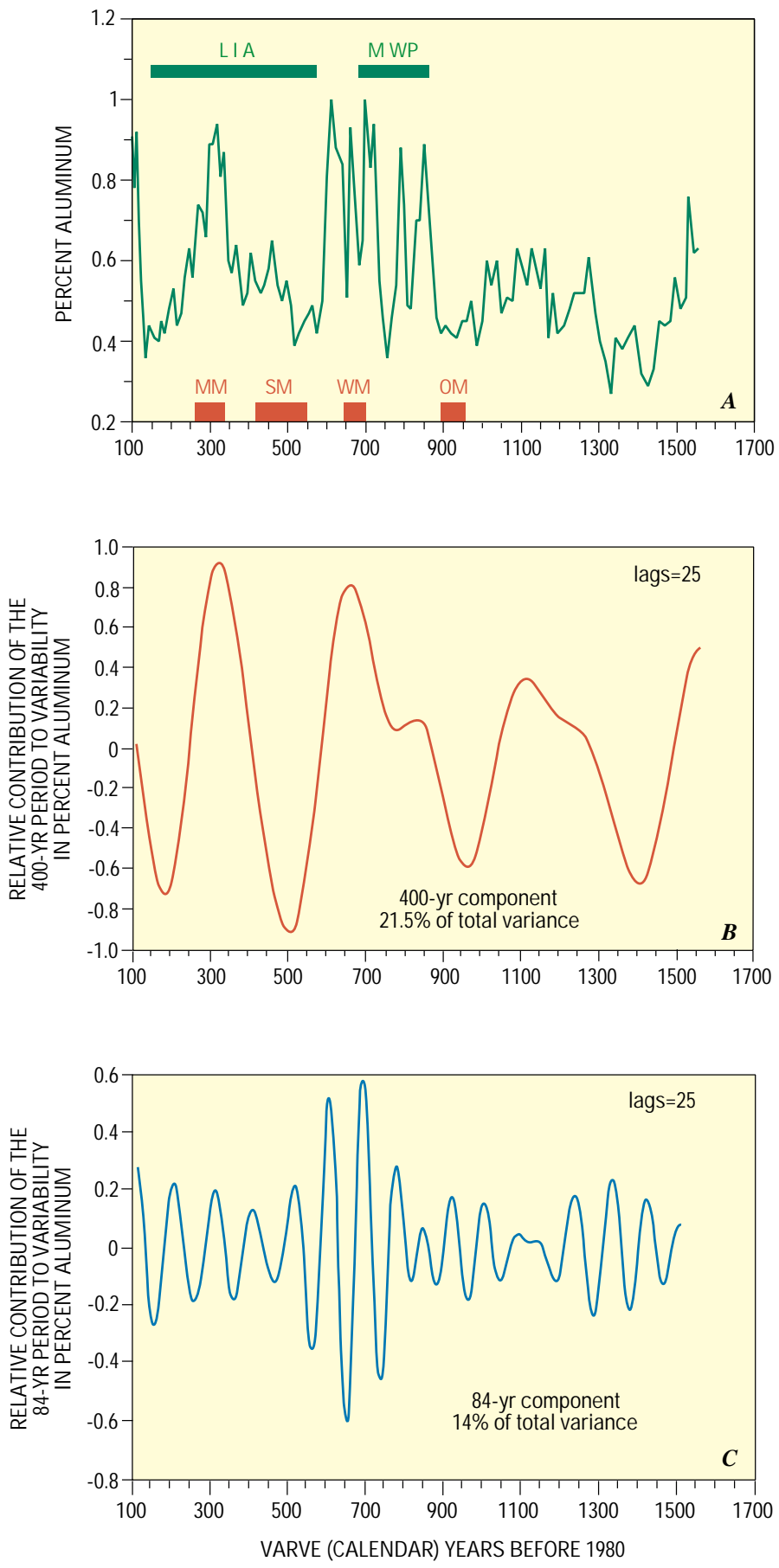

Figure 6. A, Plot of percent aluminum in bulk sediment in Elk Lake versus time in varve years for the past 1,550 yr. M M , SM,WM, and OM indicate time intervals of the Maunder, Spörer, Wolf, and Oort sunspot minima, respectively, and LIA and M WP indicate time intervals of Little Ice Age and M edieval Warm Period, respectively. B, Relative contribution of 400-yr period reconstructed by singular spectrum analysis for $\% A l$ data in sediments of Elk Lake for the past 1,550 yr. C, Relative contribution of 84-yr period reconstructed by singular spectrum analysis for percent Al data in sediments of Elk Lake for past $1,550 \mathrm{yr}$. 


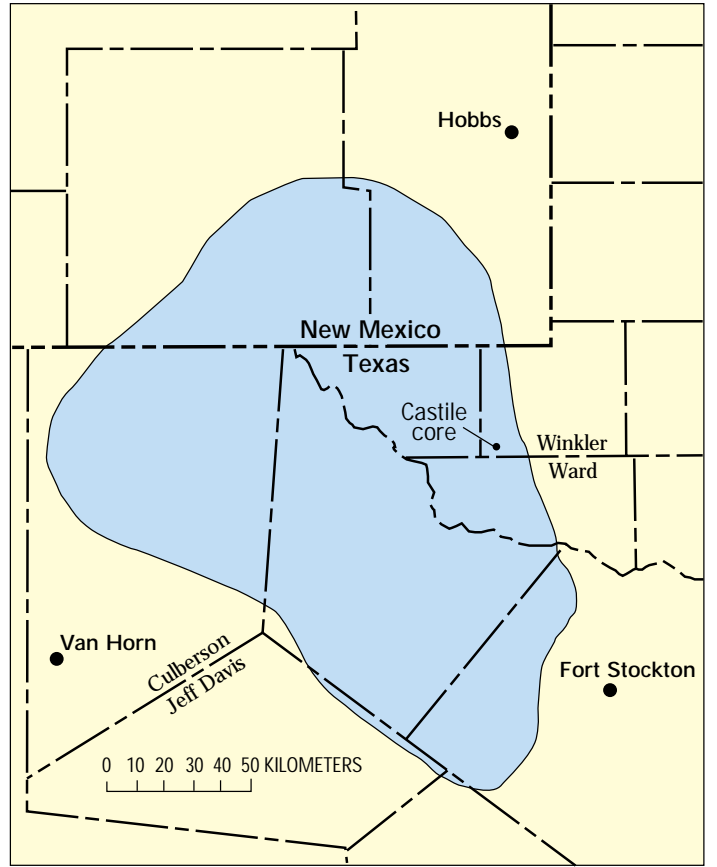

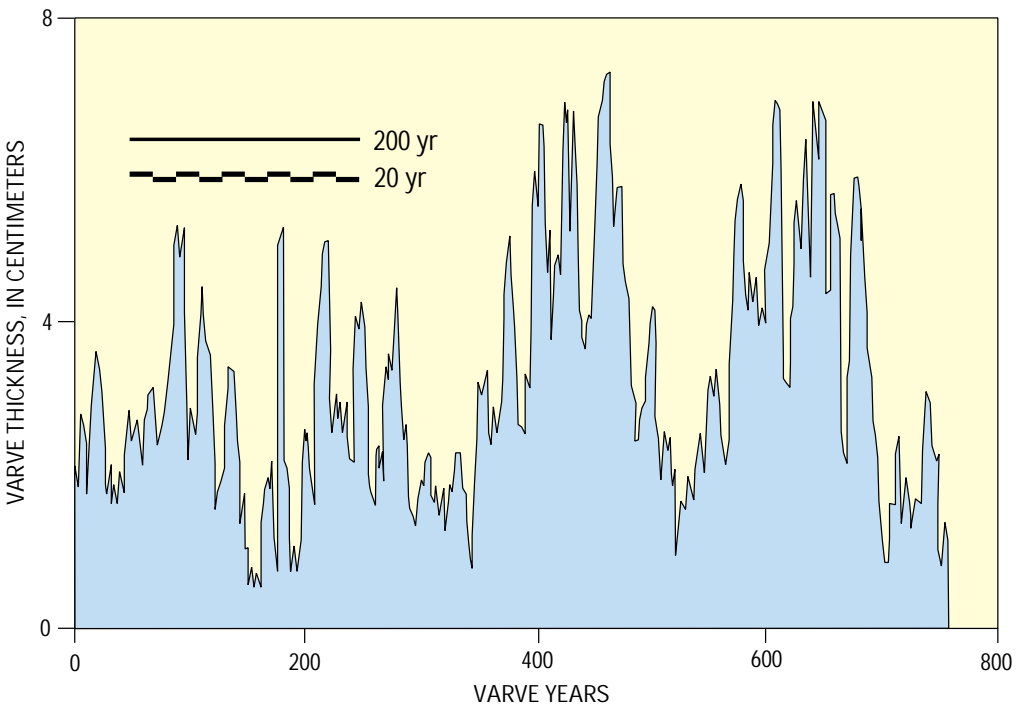

Figure 7 (left). Locality of the Permian Castile Formation core, Winkler County, Texas. (See fig. 8.)

Figure 8 (above). Smoothed (moving average) 800-year record of calcite-anhydrite varve thickness in the Halite I M ember of the Permian Castile Formation measured in a core from Winkler County, Texas. R.Y. Anderson and W.E. Dean, unpublished data. (dipole moment) during this 4,000-year mid-Holocene interval was the lowest that it has been during the Holocene (Damon and others, 1989). A weaker geomagnetic field allows more cosmic rays to enter the atmosphere producing more ${ }^{14} \mathrm{C}$. The cosmic-ray flux also affects cloud microphysical processes, and consequently the general atmospheric circulation (Tinsley and Deen, 1991; Tinsley, 1998). Dust records from annually laminated (varved) sediments from Elk Lake, Minn., show centennial-scale variations of increased dustiness during periods of reduced solar activity such as during the Little Ice Age (Dean, 1997) and the mid-Holocene (Anderson, 1992; Dean and others, 1996). Cycles with periodicities of 200 years in the dust record in Elk Lake match 200-year cycles (Suess Cycles) in radiocarbon during the 4,000-year mid-Holocene period of lower geomagnetic field (Anderson, 1992). The mid-Holocene may have been a period of greatly increased eolian (windblown) activity in parts of North America, but particularly in the Great Plains (Dean and others, 1996). A varve-calibrated eolian dust record (as indicated by aluminum content) for the last 1,500 years in Elk Lake shows distinct cycles with dominant periodicities of 400 and 84 years (fig. 6), both of which are prominent features of the maximum entropy ${ }^{14} \mathrm{C}$ power spectrum (fig. 4). The most prominent 400-year cycle coincides in time with the Little Ice Age, peaking during the Maunder Minimum (fig. $6 A, B$ ). The most prominent 84-year periodicities (Gleissberg period?) coincide in time with the Medieval Warm Period between the Oort and Wolf Minima (fig. 6A, C).

The Elk Lake record is but one of many examples in the literature of paleoproxy records purporting to exhibit cycles with periodicities matching those of solar cycles. Many are based on sparse dating so that time scales are questionable. But others, based on annual calibration (varves, tree rings, corals, and ice cores), present more convincing evidence. Commenting on the oxygen-isotope record in the recent Greenland GISP2 ice core, Stuiver and others (1997, p. 263) concluded, "The overall agreement between the timing, estimated order of magnitude of temperature change, and phase lag of the ${ }^{18} \mathrm{O}$ and $\Delta^{14} \mathrm{C}$ signals $* * *$ is suggestive of solar forcing of Greenland climate for the current millennium." But the record for the rest of the Holocene is less convincing. The dust record in the GISP2 ice core exhibits cycles with distinct periodicities of 11, 22, 90, and 200 years, believed to be associated with the Schwabe, Hale, Gleissberg, and Suess solar cycles, respectively (Ram and others, 1997; Ram and Stolz, 1999). The physical connection between solar activity and dust is postulated to be variations in precipitation patterns in the Greenland dust-source areas caused by changes in cloud cover and cloud microphysics, which in turn are affected by the cosmic-ray flux (Ram and others, 1997).

Two unpublished examples of decadal to centennial scale cycles, one ancient and one modern, further illustrate the types of paleoclimate records that might have a solar connection. The Upper Permian (240 Ma) Castile Formation in the Delaware Basin of West Texas and New Mexico (fig. 7) contains more than 200,000 annual laminations (varves) of calcite $\left(\mathrm{CaCO}_{3}\right)$ and anhydrite $\left(\mathrm{CaSO}_{4}\right)$, and anhydrite and halite $(\mathrm{NaCl})$. The Delaware Basin in the Late Permian was located near the equator on the west edge of the vast Pangea continent, but was partly isolated from the vast Panthalassa ocean to the west (Anderson and Dean, 1995). Precipitation of different evaporite minerals was the result of a delicate dynamic balance between influx and reflux of marine waters (Kirkland and others, 2000). Given this relatively simple chemical system in delicate balance, climatic fluctuations in the basin are recorded as cycles in these pure evaporite sediments. The most prominent cycle in the Castile is a salinity cycle with an average period of about 2,500 years in which the cycle begins, in the extreme, as a laminated limestone with thin calcite and anhydrite laminae. The anhydrite laminae then become thicker, and the cycle ends, in the extreme, with anhydrite and halite varves. This cycle and longer period cycles have been discussed in several reports (for example, Dean and Anderson, 1978, 1982; Anderson, 1982), but the shorter period cycles, such as the ones illustrated in figure 8 for an 800 -year record of varve thickness, have not. This record shows cycles with an average period of about 20 years superimposed on longer cycles with an average period of about 200 years. Could these be related to "double sunspot" (Hale) cycles and "Suess wiggles"? In fact, could the dominant 2,500-year cycle in the Castile Formation be related to the dominant 2,000-year cycle in the ${ }^{14} \mathrm{C}$ spectrum (Hallstadtzeit Cycle; fig. 2B)? 
For a modern example, titanium concentrations in sediment samples from a core collected in the Gulf of California off the west coast of Mexico between the mouths of the Rio Yaqui and Rio Mayo, two of the largest rivers draining the west slope of the Sierra Madre Occidental (BC6, fig. 9), exhibit striking cycles over the last 200 years with an average period of about 10 years (fig. 10). The concentration of titanium is higher in basic volcanic rocks than in average crustal rocks, and the Sierra Madre is a very large pile of volcanic rocks. The average titanium concentration in the record illustrated for core BC6 in figure 10 ( 0.35 percent) is more than twice the average titanium concentration ( 0.16 percent $)$ in sediments deposited over the same time interval recovered in core BC50 (fig. 9) taken farther offshore. The cycles are interpreted as due to greater and lesser riverine influx of volcanic rock debris from the Sierra Madre. The titanium cycles coincide almost exactly with 10- to 12-year cycles of precipitation as reconstructed from tree rings (Frittz, 1991). The cycles are more distinct in sediments deposited prior to A.D. 1940, which may reflect damming of rivers during the 20th century. Could variations in rainfall and river flow on the west slope of the Sierra Madre somehow be connected with the solar sunspot cycle as are changes in precipitation postulated for dust sources in Greenland ice cores (Ram and Stolz, 1999)?

It might be argued that if you look hard enough, you can find a correlation between solar cycles and anything, such as cycles in the stockmarket. Nevertheless, enough evidence exists to support the hypothesis of Denton and Karlén (1973) that solar cycles, as recorded in the ${ }^{14} \mathrm{C}$ variations, may be empirical indicators of paleoclimates. Cycles in sedimentary records with periodicities similar to those of solar cycles do not mean causation. The challenge to geologists and atmospheric scientists is to test these correlations with reasonable models of how solar cycles could affect the atmosphere and geologic processes at the surface of the Earth.

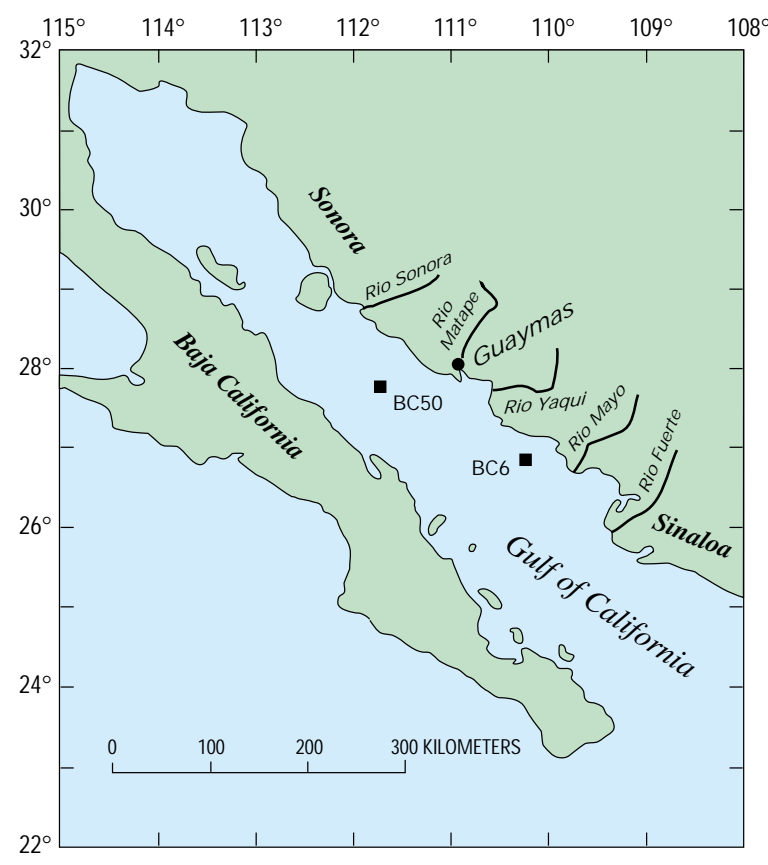

Figure 9. Locality of sediment samples of cores BC6 (fig. 9) and BC50, Gulf of California.
Figure 10. Percent titanium (Ti) versus years A.D. (red) in sediments from a box core collected in the eastern Gulf of California between the mouths of Rios Yaqui and Mayo. The record of sunspot number from A.D. 1820 to 1990 is repeated from figure 1 (green).

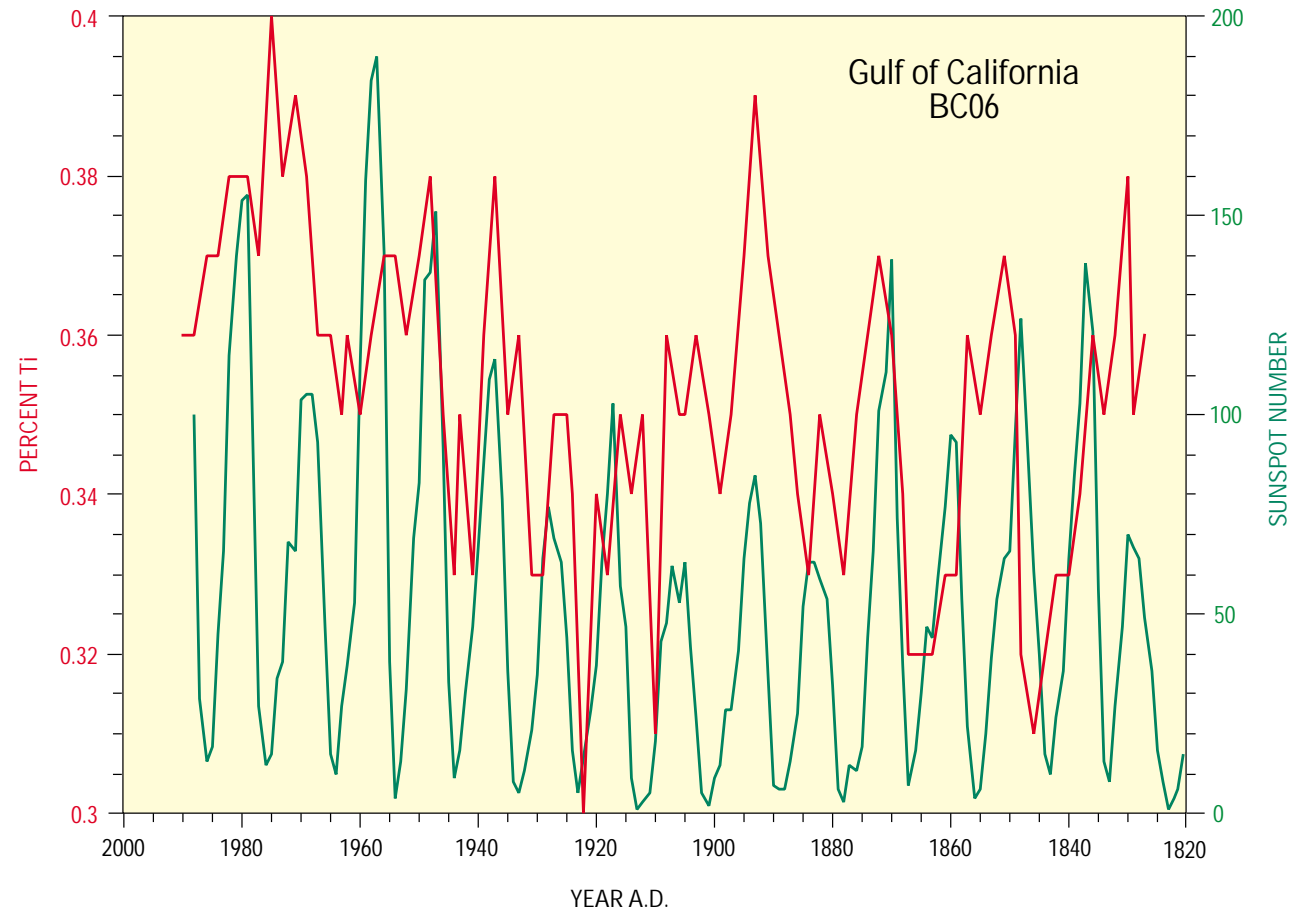




\section{References Cited}

Anderson, R.Y., 1982, Long geoclimatic record from the Permian: Journal of Geophysical Research, v. 87, p. 7285-7294.

1992, Possible connection between surface winds, solar activity and the Earth's magnetic field: Nature, v. 358, p. 51-53.

Anderson, R.Y., and Dean, W.E., 1995, Filling the Delaware Basin; Hydrologic and climatic controls on the Upper Permian Castile Formation varved evaporite, in Scholle, P.A., Peryt, T.M., and Ulmer-Scholle, D.S., eds., The Permian of Northern Pangea, Volume 2, Sedimentary basins and economic resources: Berlin, Springer-Verlag, p. 61-78.

Cliver, E.W., 1994a, Solar activity and geomagnetic storms; The first 40 years: Eos, v. 75, p. 569-576.

1994b, Solar activity and geomagnetic storms; The corpuscular hypothesis: Eos, v. 75, p. 609-613.

1995, Solar activity and geomagnetic storms; From M regions and flairs to coronal holes and CMEs: Eos, v. 76, p. 75-83.

Crowley, T.J., and Kim, K-Y, 1996, Comparison of proxy records of climate change and solar forcing: Geophysical Research Letters, v. 23, p. 359-362.

Damon, P.E., Cheng, S., and Linick, T.W., 1989, Fine and hyperfine structure in the spectrum of secular variations in atmospheric ${ }^{14} \mathrm{C}$ : Radiocarbon, $\mathrm{v}$. 31, p. 697-703.

Damon, P.E., and Sonnett, C.P., 1991, Solar and terrestrial components of the atmospheric ${ }^{14} \mathrm{C}$ variation spectrum, in Sonnett, C.P., Giampapa, M.S., and Matthews, M.S., eds., The sun in time: Tucson, Ariz., The University of Arizona Press, p. 360-388.

Dean, W.E., 1997, Rates, timing, and cyclicity of Holocene eolian activity in north-central United States-Evidence from varved lake sediments: Geology, v. 25, p. 331-334.

Dean, W.E., Ahlbrandt, T.S., Bradbury, J.P., and Anderson, R.Y., 1996, Regional aridity in North America during the middle Holocene: The Holocene, v. 6, p. 145-155.

Dean, W.E., and Anderson, R.Y., 1978, Salinity cycles-Evidence for deepwater deposition of the Castile and lower Salado Formations, Delaware Basin, Texas and New Mexico, in Symposium on the Ochoan rocks of southeastern New Mexico and west Texas: New Mexico Bureau of Mines and Mineral Resources Circular 159, p.15-20.

1982, Continuous subaqueous deposition of the Permian Castile Evaporites, Delaware Basin, Texas and New Mexico, in Handford, C.R., Loucks, R.G., and Davies, G.R., eds., Depositional and diagenetic spectra of evaporites-A core workshop: SEPM Core Workshop 3, p. 324-353.

Denton, G.H., and Karlén, W., 1973, Holocene climatic variations; Their pattern and possible cause: Quaternary Research, v. 3, p. 155-205.

Eddy, J.A., 1976, The Maunder Minimum: Science, v. 192, p. 1189-1202.

Frittz, H.C., 1991, Reconstructing large-scale climatic patterns from tree-ring data: Tucson, Ariz., The University of Arizona Press, 286 p.

Grigal, D.F., Severson, R.C., and Goltz, G.E., 1976, Evidence of eolian activity in north-central Minnesota 8,000 to 5,000 yr ago: Geological Society of America Bulletin, v. 87, p. 1251-1254.

Haigh, J.D., 1996, The impact of solar variability on climate: Science, v. 272, p. 981-984.

Kirkland, D.W., Denison, R.E., and Dean, W.E., 2000, Parent brine of the Castile evaporites (Upper Permian), Texas and New Mexico: Journal of Sedimentary Research, v. 70, p. 749-761.

Kutzbach, J.E., 1987, Model simulations of the climatic patterns during the deglaciation of North America, in Ruddiman, W.F., and Wright, H.E., Jr., eds., North America and adjacent oceans during the last deglaciation: Boulder, Colo., Geological Society of America, The Geology of North America, Volume K-3, p. 425-446.
Labitzke, K., and van Loon, H., 1993, Some recent studies of probable connections between solar and atmospheric variability: Annals of Geophysics, v. 11, p. 1084-1094.

Lean, J., and Foukal, P.V., 1988, A model of solar luminosity modulation by magnetic activity between 1954 and 1984: Science, v. 240, p. 906-908.

Lean, J.L., White, O.R., and Skumanich, A., 1995a, On the solar ultraviolet spectral irradiance during the Maunder Minimum: Global Biogeochemical Cycles, v. 9, p. 171-182.

Lean, J., Beer, J., and Bradley, R., 1995b, Reconstruction of solar irradiance since 1610; Implications for climate change: Geophysical Research Letters, v. 22, p. 3195-3198.

Ram, M., and Stolz, M.R., 1999, Possible solar influences on the dust profile of the GISP2 ice core from central Greenland: Geophysical Research Letters, v. 26, p. 1043-1046.

Ram, M., Stolz, M., and Koenig, G., 1997, Eleven year cycle of dust concentration variability observed in the dust profile of the GISP2 ice core from Central Greenland; Possible solar connection: Geophysical Research Letters, v. 24, p. 2359-2362.

Roberts, W.O., and Olson, R.H., 1973, Geomagnetic storms and wintertime $300 \mathrm{mb}$ trough development in the North Pacific-North America area: Journal of Atmospheric Science, v. 30, 135-140.

Sonnett, C.P., and Finney, S.A., 1990, The spectrum of radiocarbon: Philosophical Transactions of the Royal Society of London, v. 30A, p 413-426.

Stolov, H.L., and Shapiro, R., 1974, Investigation of the responses of the general circulation at 700 mbar to solar-geomagnetic disturbance: Journal of Geophysical Research, v. 79, p. 2161-2170.

Stuiver, M., Braziunas, T.F., Grootes, P.M., and Zielinski, G.A., 1997, Is there evidence for solar forcing of climate in the GISP2 oxygen isotope record? Quaternary Research, v. 48, p. 259-266.

Stuiver, M., and Pearson, G.W., 1986, High-precision calibration of the radiocarbon time scale, A.D. 1950-500 B.C.: Radiocarbon, v. 28 , p. 805-838.

Tinsley, B.A., 1998, Solar wind inputs to cloud microphysics through electric charge accumulation by cloud droplets: Eos, v. 79, p. 4.

Tinsley, B.A., and Deen, G.W., 1991, Apparent tropospheric response to $\mathrm{MeV}-\mathrm{GeV}$ particle flux variations; A connection via electrofreezing of supercooled water in high-level clouds: Journal of Geophysical Research, v. 96 , p. 2283-2296.

This Fact Sheet is also available online at http://greenwood.cr.usgs.gov/pub/fact-sheets/fs-0095-00/

\section{For more information please contact:}

Walter E. Dean

U.S. Geological Survey

P.O. Box 25046, MS 980

Denver Federal Center

Denver, CO 80225-0046

303-236-5760

303-236-5349 Fax

dean@usgs.gov 